\title{
College Connectedness: The Student Perspective
}

\author{
Derek A. Jorgenson \\ Laura C. Farrell \\ Julie L. Fudge \\ Andrew Pritchard
}

Everett Community College

\begin{abstract}
Connectedness and integration are essential elements of student satisfaction, academic success, and retention. Despite its importance in the lives of college students, research on connectedness has approached the concept from definitional perspectives other than those of students. This multi-study explores connectedness from the student perspective while drawing from social identity theory and student involvement theory. In Study 1, students described their experiences and perceptions of connectedness in focus groups. Study 2 built on the qualitative findings of Study 1 and empirically tested connectedness as defined by the students. Results of the study indicate the need for a student definition of connectedness and provide practical suggestions for institutions of higher education.
\end{abstract}

Keywords: Connectedness, social identity theory, student involvement theory, instrument design, higher education

College students' connection to campus life can sometimes be a mystery, but it is a vital relationship that helps with their healthy and successful college experience. Dozens of studies have explored this relationship from different angles. Some of the primary considerations include student satisfaction (Krumrei-Mancuso, Newton, Kim, \& Wilcox, 2013), student engagement (Kahu, 2013), academic integration (Tinto, 1993), early integration (D’Amico, Dika, Elling, Algozzine \& Ginn (2013) student self-efficacy (Davidson \& Beck, 2007), student-institution fit (Denson \& Bowman, 2015), the teacher-student relationship (Hagenauer \& Volet, 2014), social integration (Brooman \& Darwent, 2014), student engagement (Flynn, 2014), student assimilation (Sollitto, Johnson \& Myers, 2013), student attachment (Wilson \& Gore, 2013), expectancy and goal setting (Friedman \& Mandel, 2011, 2012), and complexity thinking (Forsman, Linder, Moll, Fraser, \& Andersson, 2014). All these explorations on student connectedness stem from the conceptual perspective of the researcher or an institutional framework.

The mystery of the students' concept of connectedness is in need of more investigation. Rovai (2002) offers a broad and holistic definition of connectedness; the feeling of belonging and the creation of bonding relationships. This definition offers what can be considered an allencompassing idea of connectedness, specifically, one that includes the students' perspective. Working within this idea of connectedness, learning and building on connectedness from the students' perspective provides academics with the ability to further cultivate healthy and successful students. By using social identity theory and student involvement theory, it becomes possible to explore the processes, sites, and values used by students to develop their sense of 
connectedness. This provides valuable insight into how institutions of higher education might facilitate interactions that lead to successful undergraduate experiences.

\section{Literature Review}

Effective learning in higher education requires successful student interaction as well as positive attitudes and perceptions regarding the setting (Aitken, 1982). Students interact in both social and academic systems of a college campus (Mannan, 2007), but interaction does not ensure integration, as individual student perceptions define relationships and memberships with the campus community (Tinto, 1987). A divide currently exists between the social and academic aspects of student life (Boyer, 1987), which is also reflected in connectedness literature (Sollitto, Johnson, \& Myers, 2013) and the lack of agreement regarding the meaning of academic integration (Braxton \& Lien, 2000). Hanover (2011) noted that institutional approaches geared toward improving retention rates, a direct signifier of student success, need to consider a holistic approach that includes both academic and non-academic factors of student happiness and success. Tinto (2011), a prominent researcher of student success and retention, addresses the topic in a more holistic manner, but emphasizes classroom interactions more than other sites of student interaction. Increased access to higher education in recent years has shifted the educational emphasis toward technical classroom skills (Philpott \& Strange, 2003), resulting in a social-academic learning divide. To bridge this divide, the campus experience needs to encompass elements of teaching and learning within the context of a social setting, which can address student development in and outside the classroom (Borden \& Gentemann, 1993; Braxton, Doyle, Hartley, Hirschy, Jones, \& McLendon, 2014; Brown, Brown, \& Littleton, 2002).

Connectedness is an overarching construct that encompasses students' sense of belongingness, integration, and satisfaction with their relationship to their institution, and may play a role in student commitment toward the institution (Rovai, 2002). Connectedness may be divided into two types. Students may feel connectedness through satisfaction with interpersonal relationships and various social groups (Cutrona, 1982; Rovai, 2002), which this study identifies as social connectedness. Students also develop connectedness to the institution through feelings of belonging and acceptance with organizations, programs, and faculty (Sidelinger \& BoothButterfield, 2010), or institutional connectedness. The existing literature on the role of student connectedness in college success emphasizes either social connectedness or academic connectedness; both bodies of research rely on researcher-defined criteria for connectedness, neglecting to ask students to express connectedness for themselves (Clark, 2005; Smith \& Zhang, 2009).

High degrees of social connectedness are associated with a legion of positive outcomes including higher levels of emotional well-being (Cutrona, 1982; Russell, Peplau, \& Cutrona, 1980), less substance abuse and better health (Blum, McNeely, \& Rinehart, 2002; McNeely \& Falci, 2004), decreased depressive symptoms (Jacobson \& Rowe, 1999), less loneliness (Cutrona, 1982; Russell et al., 1980) and decreased risk of violent or deviant behavior (Blum et al., 2002; McNeely \& Falci, 2004). A perceived lack of social connectedness can produce depression, social anxiety and jealousy (Leary, 1990), and a perception of one's surroundings as threatening and unfriendly (Swann, 1990). Undergraduates' perceived depth and quality of connectedness appears to be more meaningful than the number of people with whom a student is connected (Cutrona, 1982; Jones, 1981). A multitude of factors can affect a student's feelings of institutional connectedness. A feeling of loneliness influences the sense of community, while feeling cared 
about, valued and accepted accentuates a sense of belonging. A high-quality social life and the perception of high degrees of support, involvement, and achievement also enhance a student's sense of institutional connectedness (Cheng, 2004; Cutrona, 1982).

Many institutions recognize that gradual change and guidance into the campus community improves students' adjustment to college (Boyer, 1990). First-year college students face practical and social choices including behavioral changes (Fromme, Corbin, \& Kruse, 2008; White \& Jackson, 2004/2005), academic performance (Perry, Hladkyj, Pekrun, Clifton, \& Chipperfield, 2005), and relationship patterns (Oswald \& Clark, 2003). This transition has been associated with declining satisfaction with the feelings of social connectedness established in high school (Oswald \& Clark, 2003), as well as decreased perceptions of social connectedness and heightened feelings of loneliness and anxiety among first-year college students who no longer live with their parents (Larose \& Boivin, 1998). In a vein similar to Smith (2015) exploring an alternate conceptualization of academic integration, this study seeks a new perspective on student connectedness. This study allows students to define connectedness, both social and institutional, while exploring the theoretical salience of both social identity theory and student involvement theory.

\section{Social Identity Theory}

Social identity theory approaches connectedness from a small group perspective. Group identification, or self-categorization, often leads to a feeling of connectedness with specific groups (Hogg \& Abrams, 1988). Social identity theory explains how people develop personal identities and their perceptions of others (Abrams, O’Connor, \& Giles, 2002; Hogg \& Abrams, 1988; Tajfel \& Turner, 1979). When identifying with a group, people are prone to differentiate and compare themselves as much as possible to other groups (Hogg \& Abrams, 1988). These social comparisons allow for the development of group identifications. Group identification may be based on factors such as religion, race, sports, clubs, personal traits, or physical appearances (Hogg \& Abrams, 1988). When an identity with a specific group is created, people who do not fit into the group are considered the out-group (Tajfel \& Turner, 1979) and experience a lack of connectedness. Identification of in-groups and out-groups allows individuals to pursue participation in a particular group (Brewer, 1999), fostering greater levels of connectedness.

Group identification influences personal values and behaviors (Tajfel \& Turner, 1979). An individual may adopt group behaviors to strengthen the belief that they belong to the group (Hogg \& Abrams, 1988). Group identification differs slightly from connectedness in that identification is based on self-perceptions and self-categorizations from personal attributes and stereotypes (Hogg \& Abrams, 1988; Turner, 1991). Another difference between connectedness and group identity is that personal behaviors are influenced by group norms, and connectedness is associated with feelings of belonging and bonding (Hogg \& Abrams, 1988; Rovai, 2002; Turner, 1991). However, social identity theory fosters an understanding of connectedness through the relationship between personal identities and perceptions of belonging.

\section{Student Involvement Theory}

Student involvement theory places the student at the center of student success and claims that external factors such as campus facilities and course content have less influence in determining a student's ability to succeed than student involvement (Astin, 1984). This emphasis on the student experience provides a theoretical grounding that emphasizes the student perspective in the 
development of this study. Student involvement theory presents a direct link between student involvement and students' level of institutional connectedness, indicating higher levels of involvement will develop higher levels of institutional connectedness.

Student involvement theory states that the more involved students are in their college education, the more likely they are to succeed (Astin, 1984). Astin (1984) defines involvement as the amount of physical and psychological energy a student commits to the academic experience and notes that an "involved student is one who...devotes considerable energy to studying, spends much time on campus, participates actively in student organizations, and interacts frequently with faculty members and other students" (p. 297). A large degree of student success is attributed to the students' proximity to campus, as students living on campus have more convenient access to peer socialization events, campus activities, and services (Astin, 1973, 1977, 1982; McCluskey-Titus et al., 2002; Terenizi, Parcarella, \& Blimling, 1996).

\section{Rationale}

The goal of this research is to more clearly understand how college students perceive connectedness and how those perceptions relate to existing connectedness and student satisfaction literature. An applied approach to investigating student perceptions of connectedness is ideal for addressing the assumptions of relevant research (see Creswell \& Plano Clark, 2007). This research uses a mixed-method approach to clarify the divide between social and institutional connectedness in previous literature. Study 1 explores connectedness using focus groups in order to discover the student-defined themes and perspectives. Study 2 uses the findings of Study 1 to develop a survey and create a measure of connectedness. An exploratory factor analysis reveals the underlying factor structure of connectedness from the student perspective; variations in students' level of connectedness are explored across key demographic variables; finally, the relationships among the dimensions of connectedness are examined.

\section{Study 1}

Focus groups with traditional-age (18-25) first-year undergraduate students were conducted to discover how undergraduate students develop connections to their peers and the university, two elements of connectedness. The focus groups were guided by the following research question.

RQ1: How do first-year students perceive, describe, and experience connectedness?

\section{Participants}

Thirty first-year undergraduate students from a midsized, Midwestern, land-grant university participated in four focus groups, 19 females and 11 males. Focus groups ranged from 5-10 participants. Participants were aged 18-25 $(M=19.1, S D=1.647)$. Approximately $80 \%(n=24)$ of the participants were white; $20 \%(n=6)$ identified as Hispanic/Latino, Asian, African American, Native American, or other. The majority of participants lived on campus $(n=25)$, while other participants indicated they lived off campus $(n=5)$.

\section{Procedures}


Participants were recruited through email. The focus groups were conducted using a semistructured protocol. Focus group questions thematically related to how and where students meet others and the different types of relationships developed as first-year students. For example, students were asked, "How have you met people here?" and "What are examples of relationships you have developed with teachers or other people who work on campus?" The focus group moderator did not use the term "connectedness," but the questions were developed to describe situations that involved social and institutional connectedness.

\section{Data Analysis}

Focus group transcript analysis used a combination of open and axial coding. Data analysis began by reading the focus group transcripts to develop a comprehensive sense of the data. Open coding and an inductive approach were used to develop codes and themes. First, descriptive themes were identified from the text. Following suggestions from Strauss and Corbin (1990), descriptive codes were used to create theoretical and analytic themes that captured a more general perspective. The research team developed descriptive codes and code definitions, which lead to the development of theoretical codes. Research team members individually coded the transcripts to identify theoretical codes and reach inter-coder reliability (92\%).

\section{Results}

The results of Study 1 yielded three analytical themes: (1) social expectations versus social actions, (2) relationships with instructors, and (3) overlap of social and institutional connectedness. Social expectations versus social actions highlighted the tension between what students wanted from their college experience and what they have done since beginning their college careers. This analytical theme provided an understanding of the range of positive and negative experiences first-year students had when attempting to develop friendships. The second analytical theme, relationships with instructors, compared the different experiences students had with instructors and other university employees. Codes within this theme revealed the types of interactions students had with instructors and university employees. Interactions that focused only on academic topics were distinguished from those that included elements that demonstrated personal care for the student as an individual. Finally, students did not distinguish between social connectedness and institutional connectedness, even though previous research identifies the two as independent concepts. This observation resulted in the development of a third analytical theme, overlap of social and institutional connectedness.

Social Expectations Versus Social Actions. First among these was a disjunction between student expectations before coming to college and their actions once on campus. Students indicated they intended to establish many new kinds of social connections, but their actual tendency was to gravitate toward previously established connections or toward students with similar backgrounds. Students described either not establishing many new social connections, or establishing connections that do not meet their stated expectation of new kinds of relationships or relationships with new kinds of people.

A comprehensive listing of participant comments on this theme would be replete with the phrase "meet new people" when students described their expectations before coming to college. These comments suggested students expected their social connections to be different (e.g., more varied, more numerous, or more central to their lives), than their previous experiences. Many 
comments indicated the variety of activities and relationships students expected to join in college. Bonnie's mention of the absence of "cliquey" groups drew agreement from other participants and was a commonly repeated idea. Several participants also pointed out they expected college to be a time in which important decisions about their social connections would be made independently. When students described their actual social-connection behavior upon coming to college, their descriptions and stories depicted patterns of prioritizing pre-existing connections or seeking new connections with people with similar experiences and worldviews.

When students sought new relationships, they often restricted themselves to connections that extended their social experiences before college. This pattern appeared amplified among students whose previous friends came to college with them. As Paul said, "Yeah, I had friends that carried over from high school too, so I didn't try too hard to make new friends.” Paul's comment was particularly striking, because it indicated his expectation to "make new friends" persisted even as he described having prioritized his pre-college relationships in his actions. These two discordant ideas in the same statement illustrate how deeply the disjunction between "meeting new people" and prioritizing continuity or familiarity was embedded in students' experiences. Michael echoed other participants saying, "coming from a small town, it's easier for me to relate with people who were from small towns because we had, I don't know, we just knew what each other was talking about..." In context, the idea of knowing "what each other was talking about" was shorthand for similar life experiences, values, and assumptions about the world. Prioritizing relationships with similar people highlighted the disjunction between expectations and action.

Relationships with Instructors. The second overarching theme was the inextricable interweaving of students' personal and academic relationships with their instructors. Students saw their instructors not merely as educational providers, but as figures with whom personal relationships could be forged. Students' descriptions of instructors with whom they most felt connected did not reflect classroom teaching style or pedagogical competence, but rather the degree to which students perceived the instructor cared about them as people. As Casey described one such instructor, “... [W] [Wen you go talk to them during office hours you can talk about the stuff they do in classes and also he's interested in ... what do you want to be when you grow up, kind of stuff like that."

Owen described a connection with an instructor that began in a classroom context. However, this instructor showed enough personal interest in the student (he "was really nice") that Owen began to "stop in for a couple minutes," asocial act that had nothing to do with the academic element of Owen's education. Owen's choice to describe the instructor as "really nice" rather than professional or scholarly quality spoke to the relational element the student valued. Owen also described a positive outcome stemming from his perception that this "really nice" instructor cared about him: it led Owen to return to the instructor for other additional academic help.

As might be expected, a personal connection with an instructor can be negative, and can also influences a student's academic interaction with that instructor, as Becky recounted:

... [O]ne of my professors last semester was so intimidating, and I had a question on a test that I had taken, and I was just, like, dreading going there, I was, like, sweating and shaking and then I, like, go there and it's just like, you don't want it to be like that.

The crucial adjective "intimidating" that Becky applied to the professor is noteworthy. She did not use a term associated with his knowledge of his field, the clarity of his instruction, or the fairness of his grading. An academic interaction, a question about a test, was again refracted in the student's mind through the prism of personal connection. 
Overlap of Social and Institutional Connectedness. Social connections and the students' sense of connection to their university as an institution overlap and interweave, contrary to the assumptions of much existing literature. This theme was illustrated by the dual nature of students' personal and academic relationships with instructors and other university employees including advisors, financial aid staff, and custodial workers. This theme emerged when participants discussed the role of non-academic staff. Kathy's observation demonstrated this theme: "I don't really know them, but the people in our dining centers are just so friendly... they'll just ask the question, you know, be nice about it and they'll just, I don't know, it just makes me feel seen...” Kathy noted the importance to her was not the service provided but rather that she felt "seen." The significance of these employees was not confined to their formal institutional roles.

This overlap of personal and institutional connectedness occurred negatively as well: employees who failed to establish a personal connection were judged as performing poorly in their professional and institutional capacities. Abby described such a relationship when her advisor essentially told her to quit the program if she didn't like the major. Abby characterized her relationship with her advisor by the perceived degree to which the advisor did not care about her as a person. In context, this demonstrated the negative aspect of how students respond to not being "seen" by campus employees. It demonstrated a different way of how students viewed personal connection as inseparable from their experience of connection with the university as an institution (embodied in the people who carry out its functions).

\section{Discussion}

Key findings from Study 1 established overlapping relationships across social and institutional connectedness, suggesting from the students' perspective, the frameworks of social identity theory and student involvement theory merge. Combining the assumptions of social identity theory and student involvement theory, the relationship between new student friendships and feeling connected to a larger student body helps elucidate that belonging to groups and being active in campus life are positive indicators of student success. Previously, student involvement theory only focused on students who are institutionally involved on campus, excluding social elements. Social identity theory explains that a portion of student involvement emerges as a result of developing new friendship groups. Social and institutional aspects of connectedness appear to be interlinked, influencing one another in creating an overall feeling of connectedness.

\section{Study 2}

The themes that emerged from the results of Study 1 suggest first-year students' conception of connectedness is not fully explained independently by either social identity theory or student involvement theory. Drawing upon previous connectedness literature and qualitative findings of Study 1, Study 2 served as a platform to empirically tease apart the complex and multidimensional nature of connectedness from the students' perspective. The following research questions were posed:

RQ2: From the students' perspective, what dimensions encompass connectedness?

RQ3: How do the dimensions of connectedness differ as a function of key demographic characteristics?

RQ4: How do the dimensions of connectedness relate? 
Study 2 employed an online survey method to capture dimensions of connectedness from the students' perspective, identify the situations and relationships in which students experience connectedness, and investigate the relationship among the dimensions of connectedness, with the underlying purpose of refining the qualitative overlap between social and institutional connectedness seen in Study 1.

\section{Procedures}

The procedures for Study 2 involved a series of steps. First, scale items measuring various aspects of connectedness were developed. Second, the items were examined for content and face validity. Third, an online survey was administered to first-year students. Fourth, an exploratory factor analysis was used to examine the factor structure of connectedness from the students' perspective. Each of these steps is outlined below.

Development of scale items. Scale items were generated based on the qualitative findings of Study 1 and previous literature, with the intent of capturing students' perceptions of expectations and actions of their new and old friends (20 items), as well as relationships with faculty and other students (18 items). These items were placed on scales ranging from (1) "not at all true" to (9) "very true;" therefore high scores indicated high levels of connectedness in a variety of ways. These items were examined for content validity. The items created were determined representative of both the findings from Study 1 and connectedness literature. In order to assess face validity, survey items were given to a group of first-year students who participated in Study 1 to evaluate whether the items captured aspects of social and institutional connectedness; the students confirmed the face validity of the items.

Sampling. First-year traditional-age undergraduate students were recruited from a university-wide required course, using a purposive sampling technique (Kerlinger \& Lee, 2000). The course provided access to the target population of first-year traditional-age undergraduates. A recruitment email was sent via the course listserv. Students who qualified to participate in the study accessed the online survey through a link embedded in the recruitment email. Students who agreed to the online consent form were redirected to the online survey. Participants responded to questions about their expectations and actions of old and new friends, as well as their relationships with faculty and other students. Demographic information was also collected.

Participants. A total of 256 participants were recruited. There were 115 (44.9\%) males and 136 (53.1\%) females with five (2\%) students not identifying their sex. A total of 230 (89.8\%) students reported their age as $18-20,21(8.2 \%)$ as age $21-25$, and five (2\%) who did not report age. Participants included 228 (89.1\%) white students, 19 (7.4\%) non-white students, and nine (3.5\%) who did not identify ethnicity. A total of 194 (75.8\%) students reported living on-campus with 57 (22.3\%) off-campus students, and five students not reporting residence. The study included 48 (18.8\%) students whose hometown was 0-60 miles away, and $204(79.7 \%)$ students whose hometown was 61 or more miles away, with four students not reporting distance from hometown. The study included 77 (30.1\%) students who reported visiting their hometown a few times a month or more, and 161 (62.9\%) students reported visiting their hometown once a month or less, with 18 (7\%) students not reporting frequency of hometown visits.

In order to determine how well the sample $(N=256)$ represented the entire student population of 11, 987 students, at the university where this research was conducted, chi-square tests were used to compare distributions of biological sex, age, ethnicity, and residence. The results indicated that the sample proportions of students' biological sex $\left[\chi^{2}(d f=1)=.148, p=.70\right]$, age 
$\left[\chi^{2}(d f=1)=.04, p=.84\right]$, ethnicity $\left[\chi^{2}(d f=1)=.281, p=.60\right]$, and residence $\left[\chi^{2}(d f=1)=.08\right.$, $p=.78]$, were similar to the student population proportions, therefore allowing the results of this study to be generalizable to the university's undergraduate student population. This research took place at a Midwestern, land grant institution at which a majority of classes offered have 40 or fewer students (NDSU, 2011).

Measures of connectedness. An exploratory factor analysis using principal components extraction and varimax rotation was used to identify the underlying factor structure of connectedness. The initial analysis (including 37 items) revealed several items with low communalities, items that cross-loaded onto multiple factors, and items that failed to load onto any factor (at an adequate level of .60 or higher). Following recommendations of Conway and Huffcutt (2003), these items were dropped. The final subsequent analysis revealed five factors with eigenvalues greater than 1 that accounted for $70.16 \%$ of the variance. Table 1 reports the connectedness variables and factor loadings for each of the five factors. 


\section{Table 1. Factor Loadings Using Principal Components and Varimax Rotation}

1. I can rely on other students for personal support.

2. I can trust other students for academic advice

3. I can trust other students for personal advice.

4. I can rely on other students for academic support.

5. I can easily talk to other students about personal topics.

6. I talk regularly with other students about school topics.

7. I can easily talk to other students about academic topics.

8. I receive personal support from instructors.

9. I can trust and rely on instructors for personal advice.

10. The personal responses I receive from instructors are valuable.

11. I talk to instructors about personal interests.

12. I talk to instructors about classes on a regular basis.

13. I receive academic support from instructors.

14. Since coming to college I have remained close to my high school friends.

15. Since coming to college I see my high school friends a lot.

16. Since coming to college I have remained close with my friends from high school.

17. Before I came to college I expected to see my high school friends a lot.

18. Before I came to college I expected to maintain my friendships from high school.

19. Before I came to college I expected to meet people I didn't know before.

20. Before I came to college I expected to stay close with my friends from high school.

21. Before I came to college I expected to meet different people.

22. Since coming to college I have met people I didn't know before.

23. Since coming to college I have met a lot of new people.

24. Before I came to college I expected to meet people who have different hobbies than me.

25. My new friends at college came from a different size hometown than me.

26. Before I came to college I expected to meet people who came from a different

size hometown than me.

27. My new friends at college have different hobbies than me.

Note. Factor 1 = Student Connectedness; Factor 2 = Faculty Connectedness; Factor 3 = Connectedness with Old Friends;

Factor 4 = Connectedness with New Friends; Factor 5 = Connectedness to Diverse Friends

\begin{tabular}{|c|c|c|c|c|}
\hline 1 & 2 & 3 & 4 & 5 \\
\hline 0.868 & 0.100 & 0.097 & 0.160 & 0.098 \\
\hline 0.861 & 0.170 & 0.090 & 0.102 & 0.123 \\
\hline 0.853 & 0.099 & 0.124 & 0.172 & 0.089 \\
\hline 0.839 & 0.207 & 0.058 & 0.133 & 0.120 \\
\hline 0.815 & 0.171 & 0.124 & 0.212 & 0.060 \\
\hline 0.808 & 0.063 & 0.076 & 0.239 & 0.144 \\
\hline 0.771 & 0.059 & 0.114 & 0.235 & 0.245 \\
\hline 0.027 & 0.889 & 0.030 & -0.044 & 0.021 \\
\hline 0.005 & 0.835 & 0.132 & 0.013 & 0.114 \\
\hline 0.115 & 0.813 & 0.031 & 0.120 & 0.181 \\
\hline 0.113 & 0.785 & -0.101 & -0.065 & -0.009 \\
\hline 0.202 & 0.735 & -0.153 & -0.031 & 0.000 \\
\hline 0.346 & 0.659 & -0.115 & 0.155 & 0.039 \\
\hline-0.051 & 0.023 & 0.800 & -0.198 & 0.047 \\
\hline 0.227 & -0.062 & 0.794 & 0.177 & 0.022 \\
\hline 0.226 & -0.074 & 0.773 & 0.180 & 0.005 \\
\hline-0.020 & 0.064 & 0.744 & -0.177 & 0.164 \\
\hline 0.125 & -0.034 & 0.722 & 0.309 & 0.045 \\
\hline 0.211 & 0.024 & 0.077 & 0.873 & 0.117 \\
\hline 0.270 & 0.044 & 0.059 & 0.810 & 0.115 \\
\hline 0.211 & 0.018 & 0.123 & 0.774 & 0.239 \\
\hline 0.321 & -0.048 & 0.124 & 0.602 & 0.299 \\
\hline 0.477 & 0.060 & -0.021 & 0.600 & 0.269 \\
\hline 0.179 & 0.095 & 0.119 & 0.214 & 0.788 \\
\hline 0.110 & 0.039 & 0.080 & 0.451 & 0.746 \\
\hline 0.162 & 0.049 & 0.083 & 0.453 & 0.699 \\
\hline 0.224 & 0.129 & 0.057 & -0.010 & 0.679 \\
\hline
\end{tabular}

; 


\section{Results}

The results of Study 2 elucidated current knowledge about connectedness. In response to RQ2, connectedness is comprised of five dimensions: Student Connectedness, Faculty Connectedness, Connectedness with Old Friends, Connectedness with New Friends, and Connectedness to Diverse Friends. The first factor was labeled "Student Connectedness," and includes 7 items that account for $32.32 \%$ of the overall variance ( $\alpha=.95 ; M=6.05, S D=1.90)$. The second factor was labeled "Faculty Connectedness," and includes 6 items that account for $14.55 \%$ of the overall variance $(\alpha$ $=.90 ; M=4.35, S D=1.89$ ). The third factor was labeled "Connectedness with Old Friends," and includes 5 items that account for $10.51 \%$ of the overall variance $(\alpha=.87 ; M=5.45, S D=1.78)$. The fourth factor was labeled "Connectedness with New Friends," and includes 5 items that account for $8.3 \%$ of the overall variance $(\alpha=.88 ; M=7.47, S D=1.51)$. The fifth factor was labeled "Connectedness to Diverse Friends," and includes 5 items that account for $4.5 \%$ of the overall variance $(\alpha=.82 ; M=7.01, S D=1.55)$. These measures of connectedness were used to shed light on RQ3 and RQ4.

The results of Study 2 also provide insight about how various forms of connectedness may differ as a function of key demographic variables. In response to RQ3, logistic regressions were used to examine how students' perceptions of connectedness varied in terms of biological sex (male, female), age (18-20, 21-25), ethnicity (white, non-white), residence (on-campus, offcampus), first generation student (first generation, non-first generation), distance from hometown (0-60 miles, 61 or more miles), and frequency of hometown visits (a few times a month or more, once a month or less). It is important to note that discriminant analysis is another statistical approach that could have answered the same questions as logistic regression; however, the latter was more appropriate for the current study because the data did not satisfy the assumptions of discriminant analysis (see Mendenhall \& Sincich, 2012). The analysis revealed a significant overall model for age $\left[\chi^{2}=31.10, p<.001\right.$, Nagelkerke $\left.\mathrm{R}^{2}=.27\right]$, ethnicity $\left[\chi^{2}=14.18, p<.05\right.$, Nagelkerke $\mathrm{R}^{2}=.13$, residence $\left[\chi^{2}=23.37, p<.001\right.$, Nagelkerke $\mathrm{R}^{2}=.14$ ], first generation student $\left[\chi^{2}=14.08, p<.05\right.$, Nagelkerke $\left.\mathrm{R}^{2}=.12\right]$, and frequency of hometown visits $\left[\chi^{2}=11.26, p<.05\right.$, Nagelkerke $\left.\mathrm{R}^{2}=.07\right]$.

In order to determine the usefulness of these logistic models, classification accuracy was examined. Two of the logistic regression models (age and frequency of hometown visits) were considered useful; these obtained a 25\% improvement over the rate of accuracy achievable by chance alone. Classification accuracy of age was $92.4 \%$ (which is greater than the proportional by chance accuracy criteria of: $72 \%$ x $1.25=90 \%$ ) and frequency of going home was $70.8 \%$ (which is greater than the proportional by chance accuracy criteria of: $56 \%$ x $1.25=70 \%$ ).

The results revealed that for every one-unit increase in students' connectedness with their classmates, they are $44 \%$ less likely to be age $21-25$, when compared to students age 18-20. Similarly, for every one-unit increase in students' connectedness with new friends, they are $25 \%$ less likely to be age 21-25. Interestingly, for every one-unit increase in students' connectedness toward faculty, they are 74\% more likely to be age 21-25 (see Table 2). 
Table 2. Age as a Predictor of Connectedness

\begin{tabular}{|c|c|c|c|}
\hline \multirow[b]{4}{*}{ Connectedness Variables } & \multicolumn{3}{|c|}{$\begin{array}{l}\text { Regression 1: Age 18-21 vs. 21+ } \\
0=18-21(n=230) \quad 1=21+(n=21)\end{array}$} \\
\hline & \multicolumn{3}{|c|}{ Maximum Likelihood Parameter Estimate } \\
\hline & \multirow[b]{2}{*}{$\underline{\operatorname{Exp}(B)}$} & \multicolumn{2}{|c|}{ 95\% CI for $\operatorname{Exp}(B)$} \\
\hline & & $\underline{\mathrm{LL}}$ & $\underline{\mathrm{UL}}$ \\
\hline Student Connectedness & $0.56 * *$ & $0 . \overline{38}$ & $0 . \overline{83}$ \\
\hline Faculty Connectedness & $1.74 * *$ & 1.24 & 2.45 \\
\hline Connectedness with New Friends & $0.75^{*}$ & 0.56 & 1.00 \\
\hline Connectedness with Old Friends & 0.94 & 0.65 & 1.37 \\
\hline Connectedness with Diverse Friends & 1.22 & 0.84 & 1.77 \\
\hline
\end{tabular}

Note. $\operatorname{Exp}(B)$ is the odds ratio; $\operatorname{Exp}(B)-1=\%$ that the odds increase $(+)$ or decrease $(-)$ change in the independent variable; $\mathrm{CI}=$ confidence interval; $\mathrm{LL}=$ lower limit;

$\mathrm{UL}=$ upper limit; $* * p<.01 * p<.05$

In regard to frequency of hometown visits, for every one-unit increase in students' connectedness with other students, they are $23 \%$ more likely to go home infrequently. However, for every one-unit increase in students' connectedness to new friends, they are $19 \%$ less likely to go home infrequently (see Table 3).

\section{Table 3. Frequency of Going Home as a Predictor of Connectedness}

\begin{tabular}{|c|c|c|c|}
\hline \multirow[b]{4}{*}{ Connectedness Variables } & \multicolumn{3}{|c|}{$\begin{array}{l}\text { Regression 1: Frequent vs. Infrequent } \\
0=18-21(n=161) \quad 1=21+(n=18)\end{array}$} \\
\hline & \multicolumn{3}{|c|}{ Maximum Likelihood Parameter Estimate } \\
\hline & \multirow[b]{2}{*}{$\operatorname{Exp}(B)$} & \multicolumn{2}{|c|}{$95 \%$ CI for $\operatorname{Exp}(B)$} \\
\hline & & $\underline{\mathrm{LL}}$ & UL \\
\hline Student Connectedness & $1.23 *$ & $1 . \overline{02}$ & $1 . \overline{49}$ \\
\hline Faculty Connectedness & 1.01 & 0.86 & 1.18 \\
\hline Connectedness with New Friends & $0.81 * *$ & 0.68 & 0.97 \\
\hline Connectedness with Old Friends & 1.06 & 0.84 & 1.33 \\
\hline Connectedness with Diverse Friends & 0.97 & 0.78 & 1.21 \\
\hline
\end{tabular}

Note. $\operatorname{Exp}(B)$ is the odds ratio; $\operatorname{Exp}(B)-1=\%$ that the odds increase $(+)$ or decrease $(-)$ change in the independent variable; $\mathrm{CI}=$ confidence interval; $\mathrm{LL}=$ lower limit;

$\mathrm{UL}=$ upper limit; $* * p<.01 * p<.05$

Study 2 illuminated RQ4 by clarifying the relationships among the dimensions of connectedness from the students' perspective. The results revealed a statistically significant, positive relationship between each of the dimensions of connectedness, except connectedness with old friends and faculty connectedness, and connectedness with new friends and faculty connectedness (see Table 4). 
Table 4. Pearson Correlation Matrix: Students’ Perceived Level of Connectedness

\begin{tabular}{llllll}
\hline $\mathrm{SC}$ & $\mathrm{SC}$ & $\underline{\mathrm{FC}}$ & $\mathrm{COF}$ & $\mathrm{CNF}$ & $\mathrm{CDF}$ \\
$\mathrm{FC}$ & 1 & $0.326^{* *}$ & $0.255^{* *}$ & $0.472^{* *}$ & $.425^{* *}$ \\
$\mathrm{COF}$ & 1 & -0.003 & 0.037 & $.193^{* *}$ \\
$\mathrm{CNF}$ & & 1 & $0.242^{* *}$ & $.199^{* *}$ \\
$\mathrm{CDF}$ & & & 1 & $.489^{* *}$ \\
\hline
\end{tabular}

Note. SC = Student Connectedness; FC = Faculty Connectedness; COF = Connectedness with Old Friends; $\mathrm{CNF}=$ Connectedness with New Friends; $\mathrm{CDF}=$ Connectedness with Diverse Friends; $* * p<.01$

\section{Discussion}

The purpose of Study 2 was to refine current understanding of connectedness from the students' perspective. The exploratory factor analysis yielded five factors of connectedness that extended from the qualitative themes of Study 1 (i.e., social expectations versus social actions, relationships with instructors, overlap of social and institutional connectedness). The findings of Study 2 suggest that while there are qualitative differences between expectations and actions of students' connectedness to new and old friends, the statistical distinctions lie among connectedness with old friends, new friends, and unique qualities of friends (i.e., diversity among friends). The qualitative importance of connectedness to instructors found in Study 1 was expanded in Study 2 to highlight connectedness to faculty and other students. The students' perception of the distinction between connectedness to students and connectedness to friends is an important concept when considering the blur between "social" and "institutional" connectedness. The findings of Study 2 call to question previous connectedness literature, suggesting the need for a more nuanced conceptualization of connectedness, namely, from the students' perspective.

Rovai (2002) defined connectedness as the feeling of belonging and the creation of bonding relationships. This study acknowledges the complexity of connectedness based on this definition, and explores how connectedness is experienced and realized by students. The current study brings Rovai's definition of connectedness closer to verisimilitude, suggesting that connectedness is multidimensional and can vary based on key demographic factors of students. Connectedness, from the students' perspective, consists of an overlapping network of connectedness with old, new, and different friends, as well as with other students and faculty. The formation of connectedness is not a linear process, but a function of relational development that occurs through a series of interrelated dynamic stages. Connectedness is achieved when students are able to fulfill task roles and simultaneously meet their interpersonal needs.

Study 2 explored variations in connectedness across key demographic characteristics (e.g., biological sex, age, ethnicity, residence, first generation student, distance from hometown, and frequency of hometown visits). Findings suggest the dimensions of connectedness vary based on student age and the frequency of trips home. The variation within these factors provides a more nuanced understanding of connectedness and confirms some of the literature on college student experiences.

Connectedness manifests in two distinctly different ways based on age. Students who are 18-20 are more likely to have a high degree of connectedness with their classmates and with new friends, when compared to those aged 21-25. Alternatively, students age 21-25 are more likely to have a high degree of connectedness with faculty than are students age 18-20. While both age 
groups experience connectedness, it happens in different ways. Turman and Schrodt (2006) note, "teachers and students work together to fulfill a variety of individual and educational goals" (p. 265). While teachers and students must work together to achieve connectedness, students' age appears to have an impact on the development of connectedness to faculty.

Research indicates nontraditional students actively participate more often in the classroom, and instructors expect this increased level of participation (Fritschner, 2000). Younger students perceive classroom roles differently; they remain passive and quiet allowing instructors to impart their knowledge (Fritschner, 2000). These differences coincide with the manifestations of connectedness among younger students and are informed by social identity theory, which explains how people develop personal identities and perceptions of others and relate to those who are similar (Hogg \& Abrams, 1988; Tajfel \& Turner, 1979). Younger students may feel connected to each other based on their classroom expectations. Connectedness between instructors and nontraditional students may develop as a result of their shared expectations as well.

Study 2 also revealed students' connectedness may be contingent on the frequency of trips home. Students with a high degree of connectedness with other students appear to be more likely to go home frequently, whereas students with a high degree of connectedness to new friends are less likely to go home frequently. Student involvement theory provides a rationale for these behaviors. Students connect to their new friends through campus activities and events (Astin, 1984). As these relationships develop and connectedness increases, students are more likely to spend more time on campus with these new friends rather than return home. Student involvement fosters new relationships and connectedness among students. In turn, the increased connectedness with new friends results in the desire to become more involved. The reciprocal nature of these factors highlights the importance of connectedness and student involvement.

The absence of significant variations between first generation students and others sets this study apart from previous research. Other studies have found first generation students expect to spend less time socializing with friends in college (Murphy \& Hicks, 2006), are less engaged with their college community (Mehta, Newbold, \& O’Rourke, 2011), and are less likely to develop connections with faculty members through classes, research, or conversation (Kim \& Sax, 2009). Further research is needed to determine whether this contrary finding is unique to this study, or if the first generation factor is less salient when considering connectedness from the students' perspective.

Finally, study 2 explored how the dimensions of connectedness relate to one another. Social identity theory and social involvement theory treat social connectedness and institutional connectedness as independent constructs. Study 1 revealed that the student perspective of connectedness does not clearly distinguish between the two. Rather than mutually exclusive concepts, students identify and experience connectedness as a blended or overlapping concept. Study 1 suggested students develop feelings of connectedness through relationships with different groups. Students indicated they can feel both socially and institutionally connected based on their relationships with other students or faculty, old friends, new friends, and with diverse friends. Exploring these relationships separately, Study 2 revealed students connect both socially and institutionally through personal relationships. Furthermore, the dimensions of connectedness are predominantly positively related, with the exception of connectedness with old friends and faculty connectedness, and connectedness with new friends and faculty connectedness.

The positive relationships found in Study 2 are informed by elements of social identity theory and student involvement theory. Social identity theory explains that these positive relationships are the result of group identification and membership (Hogg \& Abrams, 1988). This

Journal of the Scholarship of Teaching and Learning, Vol. 18, No. 1, January 2018. 
coincides with the results of Study 2; students recognize the presence of different groups and their membership in multiple groups. When connectedness increases in one specific facet, the increase is also present across group memberships. Student involvement theory notes that connectedness results from interacting frequently with both faculty members and other students (Astin, 1984) rather than with just one or the other. Dimensions of connectedness are interrelated, and increases in connectedness generally appear to be experienced in tandem.

It is important to note the lack of relationship between faculty connectedness and connectedness with old friends, and connectedness with new friends, respectively. This finding suggests faculty can positively facilitate connectedness among students, a specifically academic relationship, but their influence may not extend to students' social connectedness with old and new friends. Friendship is a personal and often intimate relationship (Parks \& Floyd, 1996). Social identity theory (Hogg \& Abrams, 1988) explains that certain aspects of group identification, such as faculty connectedness, may not extend to students' personal relationships with others. In a similar manner, student involvement theory emphasizes interactions with students and instructors (Astin, 1984), rather than friends.

\section{Practical Implications}

This study reaffirms previous findings that a sense of connectedness grows from students' perceptions (Cutrona, 1982; Tinto, 1987), which can then be developed into objective measures. The results of Study 1 and 2 have a number of practical implications for those who work in and with student affairs. Students who feel connected are more likely to have better social and academic experiences during college, but from the students' perspective, these experiences are blurred. Perceived college connectedness is associated with a host of positive student outcomes, including higher emotional wellbeing, less likelihood of substance and alcohol abuse, and better health (Blum et al., 2002; Cutrona, 1982; Jacobson \& Rowe, 1999; McNeely \& Falci, 2004; Russell et al., 1980).

In general, colleges and universities should note that any interaction between a student and any campus employee plays a role in connectedness. Employees in settings where students are also forming social connectedness, such as food service or residence life staff, are well positioned to facilitate a sense of institutional connectedness. Students' perception that social connectedness is not necessarily distinct from connectedness in their academic programs provides further support for collaborations between departments of academic affairs and student affairs to provide a coherent, unified student education experience (Whitt, Nesheim, Guentzel, \& Kellogg, 2008). Examples of this include formal faculty-student mentoring programs and informal activities such as shared meals in campus dining centers. More specifically, interactions between instructors and students aged 21-25 can be encouraged and prioritized in a number of ways, as this relationship has been found to foster student connectedness when relationships with other students are not as effective.

\section{Limitations and Future Considerations}

While the primary goal of this research was to generate theory-based applicable knowledge about college connectedness from the students' perspective, future research should test the five factors of connectedness among a variety of cultural and contextual academic settings in order to refine the measures. The exploratory nature of this research provides a stepping-stone for better 
understanding connectedness; future research should use confirmatory factor analysis to test whether connectedness is a single construct comprised of five dimensions, or whether a two-factor structure may actually map onto social connectedness and institutional connectedness distinctly.

This study was also limited in that only two of the five significant overall models identified in the logistic regression analyses were useful. Future research should continue to explore how key demographic characteristics such as these, and others, may relate to students' connectedness. Research should also continue to explore connectedness from the perception of nontraditional, returning, or transfer students. Scholars may consider personal characteristics of faculty and university staff in further understanding connectedness from the students' perspective. For example, what qualities of faculty are most likely to foster connectedness (e.g., biological sex, age, personality)? What types of university staff are more influential in fostering connectedness (e.g., residence life, dining hall, janitors, academic services, financial services)?

Another limitation of the study was the sample; the generalizability of findings is limited to the university where this research took place. The findings may not be generalizable to students at other institutions due to unique campus cultures; university culture may have played a role in how the students experienced connectedness. It is important to note that while these findings may not be extended beyond the university where this research took place, the findings call into question how connectedness has been perceived in higher education. The findings of the present research may be salient at other institutions; further research should examine these concepts to see if certain patterns ring true.

\section{Conclusion}

Students perceive social and institutional connectedness as overlapping constructs, a significant consideration that can shape future studies on student connectedness and satisfaction. Connectedness is developed through relationships with friends, other students, instructors, and campus personnel. The present study provides a nuanced understanding of how connectedness emerges, how demographic variables affect its development, and how various elements of connectedness relate. From here it is important to consider how students' relationships with friends and other students may influence their ability to form connections with faculty and staff. This knowledge suggests university employees can increase students' level of connectedness through both formal and informal means. A holistic approach focused on student connectedness and satisfaction should incorporate the student perspective rather than relying predominantly on institutional conceptualizations of structure and outreach. The student experience and perception of the institution does not necessarily align with the formal structure of the organization. Adapting to this divide could be a pivotal step in the effort to better serve student needs and wants, ultimately contributing to increased student connectedness and success. 


\section{References}

Abrams, J., O’Connor, J., \& Giles, H. (2002). Identity and intergroup communication. In W. B. Gudykunst and B. Mody (Eds.), Handbook of international and intercultural communication (pp. 225-240). Thousand Oaks, CA: Sage Publications, Inc.

Aitken, N. D. (1982). College student performance, satisfaction and retention. Journal of Higher Education, 53(1), 32-50.

Astin, A. W. (1973). The impact of dormitory living on students. Educational Record, 54, 204210.

Astin, A. W. (1977). Four critical years. San Francisco: Jossey-Bass.

Astin, A. W. (1982). Minorities in American higher education. San Francisco: Jossey-Bass.

Astin, A. W. (1984). Student involvement: A developmental theory for higher education. Journal of College Student Personnel, 25, 297-308.

Blum, R. W., McNeely, C. A., \& Rinehart, P. M. (2002). Improving the odds: The untapped power of schools to improve the health of teens. Technical Report. Minneapolis: Center for Adolescent Health and Development, University of Minnesota.

Borden, V. M. H., \& Gentlemann, K. (1993). Campus community and student priorities at a metropolitan university. Paper presented at the $33^{\text {rd }}$ Annual Forum of the Association for Institutional Research, Chicago, IL. Retrieved from http://eric.ed.gov. ERIC ED 360920.

Boyer, E. L. (1987). College: The American experience. New York, NY: Harper \& Row Publishers, Inc.

Boyer, E. L. (1990). Campus life: In search of community. Princeton, NJ: Princeton University Press.

Braxton, J. M., \& Lien, L. A. (2000). The viability of academic integration as a central construct in Tinto's interactionalist theory of college student departure. In J. Braxton (Ed.), Reworking the student departure puzzle (pp. 11-28). Nashville, TN: Vanderbilt University Press.

Braxton, J. M, Doyle, W. R., Hartley, H. V., Hirschy, A. S., Jones, W. A., \& McLendon, M. K. (2014). Rethinking College Student Retention. San Francisco, CA: Jossey-Bass.

Brewer, M. B. (1999). The psychology of prejudice: Ingroup love or outgroup hate? Journal of Social Issues, 55, 429-444.

Brooman, S. \& Darwent, B. (2014). Measuring the beginning: A quantitative study of the transition to higher education. Studies in Higher Education, 39(9), 1523-1541. https://doi.org/10.1080/03075079.2013.801428 
Brown, C. E., Brown, J. M., \& Littleton, R. A. (2002). A lab without walls: A team approach to creating community. In W. M. McDonald and Associates (Eds.), Creating campus community: In search of Ernest Boyer's legacy. San, Francisco, CA: Jossey-Bass.

Cheng, D. X. (2004). Student's sense of campus community: What it means, and what to do about it. NASPA Journal, 41(2), 216-234.

Clark, M. R. (2005). Negotiating the freshman year: Challenges and strategies among first-year college students. Journal of College Student Development, 46(3), 296-316.

Conway, J. M., \& Huffcutt, A. I. (2003). A review and evaluation of exploratory factor analysis practices in organizational research. Organizational Research Methods, 6(2), 147-168. https://doi.org/10.1177/1094428103251541

Creswell, J. W., \& Plano Clark, V. L. (2007). Designing and conducting mixed methods research. Thousand Oaks, CA: Sage.

Cutrona, C. E. (1982). Transition to college: Loneliness and the process of social adjustment. In L. A. Peplau \& D. Perlman (Eds.), Loneliness: A sourcebook of current theory, research, and therapy (pp. 291-309). New York, NY: Wiley.

D’Amico, M. M., Dike, S. L., Elling, T. W., Algozzine, B. \& Ginn, D. J. (2014). Early integration and other outcomes for community college transfer students. Research in Higher Education, 55, 370-399. https://doi.org/1031007/s11162-013-9316-5

Davidson, W. B., \& Beck, H. (2007). Survey of academic orientation scores and persistence in college freshman. Journal of College Student Retention, 8(3), 297-305. https://doi.org/10.2190/H18T-6850-77LH-0063

Denson, N. \& Bowman, N. (2015). The development and validation of an instrument assessing student-institution fit. Assessment \& Evaluation in Higher Education, 40(8), 1104-1122. https://doi.org/10.1080-02602938.2014.970513

Flynn, D. (2014). Baccalaureate attainment of college students at 4-year institutions as a function of student engagement behaviors: Social and academic student engagement behaviors matter. Research in Higher Education, 55, 467-493. https://doi.org/10.1007/s11162-013-9321-8

Friedman, B. A. \& Mandel, R. G. (2011-2012). Motivation predictors of college student academic performance and retention. Journal of College Student Retention, 13(1), 1-15. https://doi.org/10.2190/CS.13.1.a

Fromme, K., Corbin, W. R., \& Kruse, M. I. (2008). Behavioral risks during the transition from high school to college. Developmental Psychology, 44(5), 1497-1504. https://doi.org/10.1037/a0012614 
Forsman, J., Linder, C., Moll, R., Fraser, D., \& Andersson, S. (2014) A new approach to modelling student retention through an application of complexity thinking. Studies in Higher Education, 39(1), 68-86. https://doi.org/10.1080/03075079.2011.643298

Fritschner, L. M. (2000). Inside the undergraduate college classroom: Faculty and students differ on the meaning of student participation. The Journal of Higher Education, 71(3), 342-362. https://doi.org/10.2307/2649294

Hanover Research (2011). Improving Student Retention and Graduation Rates. Washington, D. C.

Hagenauer, G \& Volet, S. E. (2014). Teacher-student relationship at university: An important yet under-researched field. Oxford Review of Education, 40(3), 370-388. https://doi.org/10.1080$\underline{03054985.2014 .921613}$

Hogg, M. A., \& Abrams, D. (1988). Social identifications: A social psychology of intergroup relations and group processes. New York, NY: Routledge.

Jacobson, K. C., \& Rowe, D. C. (1999). Genetic and environmental influences on the relationships between family connectedness, school connectedness, and adolescent depressed mood: Sex differences. Developmental Psychology, 35, 926-939.

Jones, W. H. (1981). Loneliness and social contact. Journal of Social Psychology, 113, 295-296.

Kahu, E. R. (2013). Framing student engagement in higher education. Studies in Higher Education, 38(5), 758-773. https://doi.org/10.1080/03075079.2011.598505

Kerlinger, F. N., \& Lee, H. B. (2000). Foundations of behavioral research (4 ${ }^{\text {th }}$ ed.). Fort Worth, TX: Harcourt College Publishers.

Kim, Y. K., \& Sax, L. J. (2009). Student-faculty interaction in research universities: Differences by student gender, race, social class, and first-generation status. Research in Higher Education, 50(5), 437-459. https://doi.org/10.1007/s11162-009-9127-x

Krumrei-Mancuso, E. J., Newton, F. B., Kim, E., \& Wilcox, D. (2013). Psychosocial factors predicting first-year college student success. Journal of College Student Development, 54(3), 247266. https://doi.org/10.1353/csd.2013.0034

Larose, S., \& Boivin, M. (1998). Attachment to parents, social support expectations, and socioemotional adjustment during the high school-college transition. Journal of Research on Adolescence, 8(1), 1-27.

Leary, M. R. (1990). Responses to social exclusion: Social anxiety, jealousy, loneliness, depression, and low self-esteem. Journal of Social and Clinical Psychology, 9, 221-229. 
Mendenhall, W., \& Sinchich, T. (Eds.). (2012). A second course in statistics: Regression analysis ( $7^{\text {th }}$ ed., pp. 355-382). New York: Prentice Hall.

Mannan, M. A. (2007). Student attrition and academic and social integration: Application of Tinto's model at the University of Papua New Guinea. Higher Education, 53, 147-165. https://doi.org/10.1007/s10734-005-2496-y

McCluskey-Titus, P., Oliver, R. S., Wilson, M. E., Hall, L. M., Cawthon, T. W., \& Crandall, P. D. (2002). The relationship between community and academic achievement in residence halls. Journal of College and University Student Housing, 30, 11-16.

Mehta, S. S., Newbold, J. J., \& O’Rourke, M. A. (2011). Why do first-generation students fail? College Student Journal, 45, 20-35.

Murphy, C. G., \& Hicks, T. (2006). Academic characteristics among first-generation and non-firstgeneration college students. College Quarterly, 9(2), ED835403.

NDSU. (2012, August 23). Residence life: On-campus student demographics. Retrieved from http://www.ndsu.edu/reslife/diversity/on_campus_student_demographics/

Oswald, D. L., \& Clark, E. M. (2003). Best friends forever? High school best friendships and the transition to college. Personal Relationships, 10, 187-196.

Parks, M. R., \& Floyd, K. (1996). Meanings for closeness and intimacy in friendship. Journal of Social and Personal Relationships, 13(1), 85-107. https://doi.org/10.1177/0265407596131005

Perry, R. P., Hladkyj, S., Pekrun, R. H., Clifton, R. A., \& Chipperfield, J. G. (2005). Perceived academic control and failure in college students: A three-year study of scholastic attainment. Research in Higher Education, 46(5), 535-569. https://doi.org/10.1007/s11162-005-3364-4

Philpott, J., \& Strange, C. (2003). 'On the road to Cambridge': A case study of faculty and student affairs in collaboration. Journal of Higher Education, 74(1), 177-95. https://doi.org/10.1353/jhe.2003.0003

Rovai, A. (2002). Sense of community, perceived cognitive learning, and persistence in asynchronous learning networks. Internet and Higher Education, 5(4), 319-332.

Russell, D., Peplau, L. A., \& Cutrona, C. E. (1980). The revised UCLA Loneliness Scale. Journal of Personality and Social Psychology, 39, 471-480.

Sidelinger, R. J., \& Booth-Butterfield, M. (2010). Co-constructing student involvement: An examination of teacher confirmation and student-to-student connectedness in the college classroom. Communication Education, 59, 165-184. https://doi.org/10.1080/03634520903390867

Smith, W. L., \& Zhang, P. (2009). Students’ perceptions and experiences with key factors during the transition from high school to college. College Student Journal, 43(2), 643-657. 
Smith, R. A. (2015). Magnets and seekers: A network perspective on academic integration inside two residential communities. Journal of Higher Education, 86(6), 893-922.

Sollitto, M., Johnson, Z. D., \& Myers, S. A. (2013). Students’ perceptions of college classroom connectedness, assimilation, and peer relationships. Communication Education, 62(3), 318-331. https://doi.org/10.1080/03634523.2013.788726

Swann, W. B. (1990). To be adored or to be known? The interplay of self-enhancement and selfverification. In R. M. Sorrentino \& E. T. Higgins (Eds.), Handbook of motivation and cognition: Foundations of social behavior. New York, NY: Guilford Press.

Tajfel H. \& Turner, J. (1979). An integrating theory of intergroup conflict. In W. Austin \& S. Worschel (Eds.), The social psychology of intergroup relations (pp. 33-47). Monterey, CA: Brooks/Cole.

Terenizi, P. T., Parcarella, E. T., and Bliming, G. S. (1996). Students’ out-of-class experiences and their influence on cognitive development: A literature review. Journal of College Student Development, 37, 149-162.

Tinto, V. (2011). Completing College: Rethinking Institutional Action. Chicago, IL: University of Chicago Press.

Turman, P. D., \& Schrodt, P. (2006). Student perceptions of teacher power as a function of perceived teacher confirmation. Communication Education, 55, 265-279.

White, H. R., \& Jackson, K. (2004/2005). Social and psychological influences on emerging adult drinking behavior. Alcohol Research \& Health, 28(4), 182-190.

Whitt, E. J., Nesheim, B. E., Guentzel, M. J., \& Kellogg, A. H. (2008). "Principles of good practice” for academic and student affairs partnership programs. Journal of College Student Development, 49, 235-249. https://doi.org/10.1353/csd.0.0007

Wilson, S \& Gore, J. (2013). An attachment model of university connectedness. The Journal of Experimental Education, 81(2), 178-198. https://doi.org/10.1080-00220973.2012.699902 